\title{
MĂRTURII ALE ÎNSTRĂINĂRII ÎN ROMANELE ITALOFONE
}

\author{
TESTIMONIES OF ALIENATION \\ IN ITALOPHONE NOVELS
}

Nicoleta Victoria LĂZĂRESCU'

https://doi.org/10.52744/9786062613242.15

\begin{abstract}
Rezumat: Articolul de față este o încercare de a expune modul în care ideea de singurătate, de abandon, este redată de către scrütoarele românce care au emigrat în Italia, descrïnd în limba țării de adopție scene dintr-o Românie necunoscută italienilor. Am ales trei femei, pentru că sensibilitatea dată de simțul maternității creează emoții puternice. Lupta lor interioară este descrisă cu o gingăşie aparte într-un limbaj simplu şi extrem de sincer. Plecând de la dezamăgirea unei profesoare ce ajunge badantă în Italia, trecând printr-un sat lipsit de mame plecate la muncă, ajungem la un copil care se maturizează prin prisma proprïlor trăiri interioare (romanul Elizei Puşcoi) şi care oferă indicii despre motivul real pentru care „profesoara - badantă” a Simonei Amariței şi mamele lui Ingrid Beatrice Coman au preferat să aleagă înstrăinarea.
\end{abstract}

Cuvinte cheie: Scriitoare Italofone; Badante; Migrație; Relații; Autobiografii

\begin{abstract}
This article examines how the idea of loneliness and abandonment is represented by Romanian writers who emigrated to Italy, as they describe in the language of the country of adoption scenes from an unknown Romania to Italian audience. Three women writers - Eliza Puşcoi, Simona Amarița and Ingrid Beatrice Coman - were selected, because their inner struggle is described with special tenderness in simple and extremely sincere language and the sensitivity arising from their maternal feelings creates strong emotions.
\end{abstract}

Keywords: Italian-Speaking Writers; Caregivers; Migration; Relationships; Autobiographies

\section{Introducere}

Ideea de libertate şi credința în „în mai bine” au făcut ca o serie de români să treacă granița „dincolo”, în Europa. De la omul simplu până la intelectuali, singuri sau împreună cu familia, cu resurse materiale sau fără, toți au dus cu ei în bagaje câte o bucată din România construită cu sufletul şi memoria lor. Imagini din țara de origine sunt zugrăvite în romane ce le descriu frânturi de istorie acelora care cunosc prea puțin

${ }^{1}$ Profesor de limbă italiană, lazarescunicoleta@yahoo.com 
despre cei care vin în căutarea unui loc de muncă cu speranța că acolo, în Italia, vor scăpa de griji.

În ultima perioadă tot auzim în media cântecul partizanilor italieni „Bella Ciao” - poate nu are nicio legătură cu articolul de față şi, totuşi - un cântec vesel, care însuflețeşte, dă curaj. Acest cântec îşi are rădăcinile în nordul Italiei, în Valea Po, datând aproximativ din 1906. Pe ogoarele fertile de orez, femeile care lucrau ca sezoniere cântau melodia ca o modalitate de a face față unei munci foarte grele şi slab plătite. Urmate de refrenul „oh bella ciao”, după fiecare două linii, versurile apar aproape ca o notă în jurnal a muncilor zilnice. Cântecul începe cu „dimineața când m-am ridicat/ la orezărie trebuie să merg”, printre „insecte şi țânțarï” şi prezența malefică a supraveghetorului, care este redat drept „ şeful stă cu bastonul "2.

Puterea lirică a melodiei vine din fiecare linie care creşte în intensitate şi ilustrează că autoarea necunoscută a melodiei nu este o victimă. Ea este, de fapt, rezistentă şi aşteaptă cu răbdare momentul în care totul se va transforma, lucru amintit în ultima linie: „dar va veni ziua când noi toți vom lucra în libertate" 3 . După cum vom vedea în rândurile următoare există o strânsă legătură între acest cântec şi lucrările scriitoarelor alese pentru articolul de față. O badantă, un sat fără mame, un copil dezorientat, o Românie înainte şi după comunism sunt personaje - imagini ale lumii pe care Italia trebuie să o cunoască.

În ultimii douăzeci de ani, Italia a devenit o destinație pentru fluxuri migratorii tot mai intense din diferite părți ale lumii, transformându-se dintr-o țară de emigrare într-o țară de imigrație. Etnicitatea populației italiene s-a schimbat în ansamblu: sunt din ce în ce mai numeroase cuplurile mixte, copiii imigranților frecventează şcolile publice, străinii primesc permis de şedere sau cetățenia italiană.

Literatura italiană scrisă de imigranți este o consecință a acestui fenomen: la mai bine de două decenii de la începutul mişcărilor migratorii, există diferite lucrări ale străinilor. Unii autori au scris deja în propria limbă, dar pentru alții experiența migrației a fost motivul care i-a determinat să scrie.

\footnotetext{
${ }^{2}$ Alla mattina appena alzata

o bella ciao bella ciao bella ciao, ciao, ciao

alla mattina appena alzata

in risaia mi tocca andar.

E fra gli insetti e le zanzare

o bella ciao bella ciao bella ciao ciao ciao

e fra gli insetti e le zanzare

un dur lavoro mi tocca far. https://en.wikipedia.org/wiki/Bella_ciao

3 „ma verrà un giorno che tutte quante/ lavoreremo in libertà”, https://en.wikipedia. org/wiki/Bella_ciao
} 
În perioada 1990 - 1992, sunt publicate primele cărți scrise de imigranți: sunt texte autobiografice care povestesc experiențele sosirii în Italia, denunțând rasismul şi dificultățile întâmpinate, acționând ca suport documentar pentru dezbaterile asupra primirii străinilor. În ciuda încercărilor de standardizare a limbii şi a genului literar, primele texte ale literaturii migraționale se disting prin tematica lor. Scriitorii aduc cu ei o tensiune lingvistică care reprezintă trecerea de la limba țării de origine la aceea a țării de sosire.

În ceea ce priveşte viziunea față de nativul italian, migrantul român are un sentiment ambivalent oscilând între admirație şi critică: prima, pentru că nativul aparține acelei lumi care i se refuză străinului; a doua, pentru că străinul se simte singurul care are o biografie demnă de cunoscut. Adesea, în textele analizate, adolescenții și copiii sunt prezenți: prezența lor este parțial explicată de istoria personală a autorilor, dar reprezintă şi, la nivel simbolic, încercarea de a recupera memoria, nevoia de a crea un substrat cultural chiar şi într-un ținut străin.

\section{Simona Amariței}

Originară din Rădăuți, licențiată în matematică, profesoară timp de optsprezece ani, ajunsă îngrijitoare pentru persoane vârstnice (it. badante) la Torino, Simona Amariței conduce asociația culturală „Bucovina” cu care este foarte activă în mediul cultural torinez promovând imaginea Românei în Italia. În anul 2006 publică o cărticică intitulată „Guardami negli occhi. Diario di una badante” (,Priveşte-mă în ochi. Jurnalul unei îngrijitoare"). O mărturie delicată, uşor ironică şi, totuşi emoționantă a unei intelectuale care îşi ia viața în propriile mâini, pornind de la copilăria în familie până la momentul despărțiirii de locul natal şi sosirea în Italia. Nevoia de accentua trecutul nu este atât de mare cât este pentru prezentul femeii care, întărite în interior, găseşte curajul de a privi în față realitatea chiar mai dură, - un prezent care evidențiază aspecte crude şi dureroase, care pare să se fi oprit lăsând viitorul să se întrezărească doar într-o fărâmă de speranță şi nimic mai mult.4

Roberto Merlo afirmă că „această cărticică” se situează la jumătate de drum între „sfâşierea părăsirii locurilor familiare şi a familiei şi greutățile construirii unei noi vieți şi unei noi identitățî" (Melo 2000, 496). Scrisul este pentru autoare o modalitate de a depune mărturie despre marginalizarea în care trăieşte emigrantul: trebuia să spună cine este, să arate că poate face mai mult de atât. Ținutul natal, familia,

4 „Donne Migranti Che Scrivono In Italiano: Il Caso Della Romania - Concorso Letterario Nazionale Lingua Madre”. Concorsolinguamadre.It, 2020, https://concorsolinguamadre. it/donne-migranti-che-scrivono-in-italiano-il-caso-della-romania/. Accessed 19 June 2020. 
căsătoria eşuată, cu traumele după divorț, copilul lăsat în țară, deziluzia trăită în Italia de către profesoara devenită badantă sunt evocate în cuvinte simple, dar sincere, lăsând cititorul să simtă dezamăgirea în fața crudei realități.

Titlul simplu este destul de sugestiv invitând parcă la reflecţie asupra acelei persoane, care dincolo de o simplă îngrijitoare este un om, un intelectual, care se lasă pradă umilinței printre străini - ochii sunt „oglinda sufletului” - suflet cu deziluzii şi amărăciuni, cu dureri.

\section{Ingrid Beatrice Coman}

Ingrid Beatrice Coman s-a născut în România în 1971. La douăzeci şi trei de ani îşi părăseşte patria pentru a se muta în Italia, unde îşi continuă studiile şi se dedică pasiunii pentru literatură. Începe să adopte limba italiană ca limbă de scris şi participă la ateliere de ficțiune. Datele despre biografia personală a autoarei nu sunt multe, autoarea preferând să le rezume pe website-ul oficial: mută”.

A fost odată ca niciodată o fetiță pe care toată lumea o striga ,fetița

Era timidă şi vorbea foarte rar. Era închisă în ea şi se limita la a observa cu atenție fără să rostească nici un cuvânt. Tăcută, era mereu gata să se ascundă atunci când cineva i se adresa, în cine ştie ce ungher ascuns al casei sau al minții sale.

Cam aşa ar putea începe povestea mea ca scriitor. De altfel fetița aceea încă mai păstrează multe dintre răspunsurile mele.

Numai Dumnezeu ştie de câte ori am încercat să o schimb, să o modelez şi să o fac mai guralivă, mai "sociabilă", mai placută în ochii părinților ei, dar, vai mie, fără mare folos. Ea era plămădită în felul ei şi oricât aş fi învinuit-o sau pedepsit-o, ea nu putea să devină ceea ce nu era.

Aveam să înteleg doar cu mulți ani mai târziu cât de neprețuită era ea pentru mine.

Fetița aceea, în ciuda faptului că nu scotea nici un cuvânt, era inzestrată cu un har aparte care avea să răzbească prin tăcerea sa precum o floare răzbate prin țărâna întunecată şi densă: ştia să asculte.

Copiii veneau să îmi povesteasca pățaniile lor. Cumva, fără să-mi dau seama, le dădeam senzația celei care ştie să asculte, a celei care poate să ducă mai departe o poveste şi să păstreze o amintire fără să o ştirbească sau să o risipească. Nu vorbeam, dar începusem deja să mâzgălesc poveşti.

Scriitoarea din mine se trezise deja la viață şi chiar şi astăzi, după atâta amar de vreme, atunci când scriu, simt că am încă ochii şi inima acelui copil, pentru că doar când țin în mână stiloul cu o intenție genuină, lăsând magia să-mi alunece sub degete, pot cu adevarat să scriu aşa cum îmi doresc.

Scrisul meu a fost întotdeauna un mod de a asculta. Eu ascult durerea şi bucuria lumii şi apoi le aştern pe hârtie. Cărțile mele sunt ferestrele mele spre lume. 5

5 „BIOGRAPHY - Ingrid Beatrice Coman,” Ingrid Beatrice Coman, 2020, https://ingrid 
Prima poveste publicată în limba italiană este o poveste plasată în Rusia comunistă („Evghenij che torna ...”) urmată de alte poveşti publicate în diverse antologii. Primul său roman, „Oraşul lalelelor” (it. La città dei tulipani), este dedicat poporului afgan şi înfățişează povestea oamenilor obişnuiți, eroi anonimi ai unui război zilnic care trebuie câştigați sau pierduți în tăcere. Ceea ce caracterizează primele două romane ale lui Coman este alegerea de a nu vorbi despre România: Oraşul lalelelor este plasat în Afganistan, iar Ceaiul la Samovar în gulagul Uniunii Sovietice, după cum spune şi subtitlu - povestea este plasată în închisoarea minieră siberiană din Kolyma. Scenariul este constituit în ambele cazuri de țări chinuite de război, unde supraponderarea, violența, sărăcia, devastarea domină relațiile dintre indivizi, unde moartea stă în permanență la pândă. Lalelele din Oraşul lalelelor sunt de fapt simbolul a ceea ce pulsează vital sub dărâmăturile afgane; iar ceaiul de iasomie este băutura pe care Aljosha, prizonierul politic rus care a avut rara ocazie de a se întoarce acasă, o bea cu Vera, femeia de care s-a îndrăgostit. De la aceste indicii până la complot, cu siguranță, se poate spune că există un fir de optimism tenace la Coman, un sentiment care o conduce, dacă nu să recompună devastările materiale şi psihologice ale personajelor şi ale meleagurilor lor, ci să deschidă străluciri de speranță şi reconstrucție atât a locurilor cât şi a sinelui. În Ceaiul la Samovar se acordă o atenție deosebită femeilor, solidarității dintre ele, corpurilor lor epuizate de sarcini adesea nedorite şi torturate de violența soților lor, bărbaţi superficiali, infantili, iresponsabili, violenți. „Femeile sunt puternice ca nişte cămile, ele țin orice. Nu este nevoie să vă faceți grịi”, $s$-a auzit o dată pe culoarul spitalului de la un bărbat care şi-a adus soția să nască. Apoi şi-a aprins pipa şi a început să vorbească despre lucruri mai importante: afaceri, politică şi război. (Coman 2005, 13)

Cel de-al doilea roman este dedicat „memoriei a milioane de ființe umane, bărbați şi femei, care merg către cel mai îndepărtat iad de pe pământ şi nu s-au mai întors niciodată; familiulor care au aşteptat degeaba ani întregi; copiilor orfani crescuți ca florile sălbatice prinşi între gratiile sistemului; celor care încă plâng peste o fotografie albnegru de acum mulți ani şi celor care merg să aducă o floare la un mormânt fără nume" şi aparține - după cum se explică în prefața cărții, propunându-se o paralelă cu $O$ zi din viața lui Ivan Denisovici de Alexander Soljenițîn - genului literaturii de închisoare. Viața de zi cu zi a prizonierilor considerați „duşmani ai poporului” - artişti, savanți, jurnalişti disidenți - este descrisă în detaliu cu o intensitate crescândă. Personajul Karpov este definit ca „prieten al poporului”, un deținut comun căruia i

beatricecoman.com/biography/\#1482147212416-b3c99e7d-cbb3. Accessed 19 June 2020. 
s-au încredințat atribuții de control pe care le exercită cu o violență fără precedent. La final, ajung aşa-numitele amnistii progresive, care aduc libertate unora; dar pentru toți, sau aproape toți, eliberarea vine prea târziu, „când trecutul tău este mort şi viitorul indiferent” (Coman 2008, 130), la ştirea că sunt amnistiați unii prizonieri reacționează sinucigânduse. Abilitățile introspective remarcabile şi forța narativă se pot observa pornind de la dialogul dintre Vera şi Aljosha care, la mansardă, în faţa unei cutii care conține obiecte sărăcăcioase (un ciorap, o cârpă ...) şi câteva documente, reactivează amintiri din trecut despre zilele din închisoare.

Tot în 2008, Coman publică o colecție de poveşti, Nu stingeți lumina $^{6}$, legate între ele printr-un fir comun constituit prin relația dintre copii şi adulți: copiii care „poartă torțe”, aducându-i mai aproape de colțurile întunecate ale existenței noastre ca adulți - războiul, sărăcia, rândul pentru a lua pâine sau rândul pentru a intra într-o tabără nazistă şi adulții care încearcă să „se descurce cu ei înşişi şi cu cele mai ascunse părți ale sufletului lor" (Coman 2008, 5). Temele prieteniei şi ale singurătății se întorc; dorința disperată de libertate, dar şi incapacitatea de a o întâmpina după ce a aşteptat prea mult; „amărăciunea celor care, într-o țară străină, nu pot simți acasă, oboseala vieții care ne duce uneori să ne predăm sau iubirea care este în schimb capabilă să se recreeze din nimic" (Coman 2008, 5). Reflecția asupra cruzimii şi violenței exercitate în detrimentul ființelor vii, inclusiv a animalelor, ucise pentru a obține hrană, apare şi ea. Dar nici în această colecție nu lipseşte interesul pentru relația de prietenie şi solidaritate, în general între femei, pe baza cărora este adesea articulată relația efectivă şi de durată între ființele umane. Volumul se încheie cu monologul care dă titlul cărții, Nu stingeți lumina, în care este pusă în scenă figura unei persoane demente, care, datorită condiției sale psihice, este autorizată să spună adevărul dincolo de convenția socială şi oportunism.

$\mathrm{Cu}$ romanul Pentru cine cresc trandafiri, Coman decide să scrie despre România, stabilind narațiunea într-un oraş din Moldova, în ultimele luni de comunism. În cadrul unei poveşti care permite autorului să ia în considerare viața de zi cu zi a regimului din punctul de vedere al unei fete tinere (Magda) şi al profesorului ei (Catălin), cu intenția de a tăia legăturile cu trecutul. Apar teme despre egalitate (inexistentă -,,ceea ce a făcut oamenii să fie smeriți şi neputincioşi în acelaşi mod, în cursa grea pentru supraviețuire" (Coman 2010, 51), solidaritate (întâlnită în anii sărăciei şi, invers, inexistente în prezent) neînțelegere, în ochii Magdei,

${ }^{6}$ Italiană: Non Spegnete la luce. 
Le mie migliori lezioni di solidarietà le ho apprese allora. [...] Oggi non ci manca mai il pane. Ma se una sera, per distrazione o dimenticanza, dovessi finirlo e trovarmi ad averne bisogno, non mi sognerei mai di bussare alla porta del mio vicino a chiederlo. Né lui lo farebbe. L'abbondanza nelle nostre case ci ha chiuso la porta dell'uno verso l'altro. (Coman 2010, 3-4)

(Atunci am învățat cele mai bune lecții ale mele de solidaritate. [...] Astăzi nu ne lipseşte niciodată pâinea. Dar, dacă într-o seară, prin distragere sau uitare, ar fi trebuit să o termin şi să mă găsesc în nevoie, nu aş visa niciodată să bat la uşa vecinului meu, pentru a o cere. Nici el. Abundența în casele noastre ne-a închis uşa unul altuia.)

a regimului comunist. Se insistă asupra şantajului şi violenței (Ştefan, fiul unui lider de partid, o va face pe Magda să se întâlnească cu Cătălin doar în schimbul unei relații sexuale consumate). În cele din urmă, revine punctul de vedere optimist al autorului, care îl face pe Ştefan să se pocăiască şi care o determină pe autoare să scrie cuvinte de compasiune atât pentru victime, cât şi pentru călăi:

Nu au fost nici câștigători, nici învinşi, ci doar ființe umane care au fost piesele unui mecanism complex şi misterios, care ani de zile le deformase şi distorsionase. [...] Victima şi călăul, călăul şi victima: cât de fragilă, aproape imperceptibilă, este diferența dintre cei doi. Poate că inamicul nu ne este atât de străin pe cât pare, iar granița dintre bine şi rău nu merge departe în lume, ci prin inima fiecăruia dintre noi. (Coman 2010, 154, 167)

Încă o dată prevalează o anumită idealizare a ființelor umane, cu privire la care încrederea într-o viitoare palingeneză totală. Romanul încredințează punctului de vedere al tinerei Magda sarcina de a evidenția cruzimea, abuzul şi nedreptățile săvârşite de ființele umane, în timp ce perspectiva bărbatului, Cătălin se deschide asupra luptei împotriva abuzurilor regimului, asupra idealismului: un fel de roman de formare dublă al cărui complot şi ale cărui rezultate sunt susținute de o puternică tensiune spirituală.

„Badante per sempre” („Badante pentru totdeauna”), roman bilingv ilustrează povestea unei mame nevoită să plece din țară pentru a-şi putea întreține copiii rămaşi acasă.7

Multe s-au spus despre femeile care şi-au lăsat în urmă copiii ca să-i apere de nevoi, plecând la muncă în străinătate. Badante, cum li se spune, un termen care a traversat granița şi a intrat de drept în vocabularul românesc. Judecate, acuzate, puse la zid, de puține ori au avut şansa să se ridice şi să se apere.

7 „Books - Ingrid Beatrice Coman.” Ingrid Beatrice Coman, 2020, https://ingridbeatrice coman. com/books/. Accessed 19 June 2020. 
Veşnic dispuşi să aruncăm prima piatră, rareori ne uităm în urmă să vedem cât de mult a durut.

Cartea aceasta nu-şi pleacă urechea la sunetul sec al pietrelor. Au căzut prea multe ca să le mai numărăm. Ea încearcă doar să simtă intervalul tăcerii dintre o piatră şi alta. Tăcerea aceea este o piatră nearuncată. Şi tocmai în tăcerea aceea, în spaţiul acela de lovitură neîntâmplată, s-a aşternut pe hârtie această poveste. (Ingrid Beatrice Coman despre „Badante pentru totdeauna”) 8

La începutul anilor 90 emigrarea românească în Italia era încă un fenomen limitat. Acum, românii din Italia sunt comunitatea străină predominantă şi au trecut de milionul de rezidenți, context în care Ingrid scrie un text bilingv, care alternează poveştile româneşti cu traducerea lor. Este o colecţie dedicată italienilor şi migranţilor în acelaşi timp, şi poate chiar celor care au rămas acasă, iar italianul pur şi simplu nu-l cunoaşte.

Ingrid Beatrice Coman a povestit despre „oameni obişnuiți, eroi anonimi ai unui război zilnic care trebuie câştigați sau pierduți în tăcere"9. De data aceasta sunt poveştile a zece copii, iar războiul lor fiind de a supraviețui absenței părinților plecați la muncă într-o țară străină. „Copii rămaşi în urmă” în România sunt în număr de aproximativ 350.000, număr ce nu vorbeşte despre suferință, durere, aşteptare.

Culegerea bilingvă de poveşti, semnată de Ingrid B. Coman, ne oferă o mie de idei de reflecție. Construcția narativă foarte interesantă se sprijină pe cele zece poveşti ale celor zece copii, poveşti ce nu sunt separate, ci care comunică între ele, având ca elemente comune: viciul şi virtutea - abandonăm pentru a satisface viciile, plecăm într-o călătorie care va naşte virtuți, o singurătate care generează pentru copil o trezire mentală, o pregătire la copil („O jucărie pentru oameni singuri”)10, care face legăturile mai puternice, care împinge copilul lăsat singur la o maturizare timpurie, la o creştere în grabă.

Cele zece poveşti arată emoții diverse trăite de copii: este de remarcat impactul cu casa de amanet, plecarea bruscă a mamei, uneori chiar a tatălui (ca în poveştile „Nu mă atinge” sau „O lume perfectă”), despărțirea părinților (cazul părinților Irinei din „Nu mă atinge”), moartea rudelor apropiate („O jucărie pentru persoane singure”) etc -

\footnotetext{
8 A.D.R.I., Associazione. "Badante Pentru Totdeauna (I) De Ingrid Beatrice Coman." Associazione Donne Romene In Italia - A.D.R.I., 2020, https://dumitrachesilvia. wordpress.com/2015/o4/24/badante-pentru-totdeauna-i-de-ingrid-beatrice-coman/. Accessed 19 June 2020.

9 „Villaggi Senza Madri.” D.It Repubblica, 2020, https://d.repubblica.it/attualita/ 2013/05/14/news/infanzia_romania_orfani_bianchi-1648586/. Accessed 19 June 2020.

10 Pavel Cassese, Diana. "Recensione N. 33: "Il Villaggio Senza Madri” Di Ingrid Beatrice Coman.” Letterranza, 2020, http://www.letterranza.org/recensione-n-33-il-villaggiosenza-madri-di-ingrid-beatrice-coman/. Accessed 19 June 2020.(trad. ns.).
} 
toate momentele obositoare pentru care un „băiețel” se confruntă cu responsabilitatea adulţilor şi pentru care autorul avertizează la început: „Zece. Zece copii care aveau ceva de spus (...) nu am făcut mare lucru. Tocmai am ascultat. (...) Am făcut primul pas în tăcerea lor. Invit alte stilouri să-l facă pe al doilea, şi apoi al treilea, până când toate vocile care nu au fost încă auzite au găsit inima potrivită să le întâmpine"11. Foarte interesantă este şi delicatețea care se ascunde în cuvintele: „Tocmai am ascultat, în linişte respectuoasă, în acele momente sacre ale zilei în care totul este tăcut (...) şi apoi poți auzi, abia şoptit, vocea ascunsă şi misterioasă a celor care nu vorbesc niciodată, dar trimit vibrațiile inimii lor în lume, pentru ca cineva să le poată aduna şi să le spună" (Coman 2012). Aceasta este viziunea despre rolul scriitorului: de a colecta vibrațiile inimii, de a le transpune în scris. Această colecție de poveşti devine un fel de jurnal de înțelepciune cu rolul de a atrage noroc şi de a zdrobi dificultăți.

\section{Eliza Puşcoi}

Eliza Puşcoi este o altă scriitoare româncă care încearcă să vorbească italienilor despre România. Eliza s-a născut la Bucureşti, în 1975. Marcată de divorțul părinților se retrage în compania fidelă a cărților şi a prietenilor. Pasionată de limba italiană încă de la paisprezece ani, Eliza începe să scrie poezii. Adultă, ajunge în Italia, la Rocca di Papa, lângă Roma, unde se şi căsătoreşte. Începe să scrie poveşti pentru cei doi copii ai ei, Federico şi Maria, care desenează personajele poveştilor şi care, la rândul lor scriu şi ei poezii. Publică poezii în diverse antologii italiane fiind cuprinse şi poeziile copiilor într-una dintre acestea. În 2015, beneficiind de sprijinul soțului, publică „Matteo e la colomba bianca” („Matei şi porumbelul alb”), o carte de povești pentru copii, apărută în ediție bilingvă italiană-română, la editura Minela din Bucureşti. În cadrul unui eveniment cultural, în 2010, la Muzeul Civic din Albano, invitată de către Roberta Trombetta, Eliza descrie „Crăciunul românesc”. La Rocca di Papa, împreună cu profesorul Bob H. Salmi, organizează „Ziua poeziei şi a basmelor”. Îi sunt publicate câteva poezii între 2011 şi 2018, în acceaşi perioadă fiind invitată să colaboreze cu şcolile din Rocca di Papa, Colle di Fuori, Ariccia şi Genzano, lucrând direct cu copiii şi profesorii. Leagă prietenii strânse cu profesoarele Georgeta Fudulache (desenele de pe coperta romanului îi aparțin) şi Măndica Neagu, acestea sprijinind-o în publicarea romanului Eli col cappotto rosso (Eli cu paltonul roşu) ${ }^{12}$ (2020).

\footnotetext{
${ }^{11}$ Pavel Cassese, Diana. "Recensione N. 33: "Il Villaggio Senza Madri” Di Ingrid Beatrice Coman.” Letterranza, 2020, http://www.letterranza.org/recensione-n-33-il-villaggiosenza-madri-di-ingrid-beatrice-coman/. Accessed 19 June 2020. (trad. ns.).

12 Titlul complet este Eli col cappotto rosso e la caduta di Ceausescu.
} 
În romanul său, Eliza Puşcoi ne invită la o călătorie în timp (din copilărie până la maturizare, de la cel de-al doilea război mondial până la căderea regimului Ceauşescu şi perioada următoare), şi în spațiu (în lumea fanteziei, a imaginației și lumea cea reală cu experiențe care vor să fie date uitării): „Un intreccio tragicomico di realtà e fantasia, attraverso le colline della Moldavia e le vie di Bucarest..."(O împletire tragicomică de realitate şi fantezie, prin dealurile Moldovei şi străzile Bucureștiului ...) (Puscoi 2020, 2) după cum îl descrie autoarea la începutul cărții.

Pe lângă autobiografia construită în stilul romanului modern de formare (Bildungsroman), după cum îl cataloghează Georgeta Fudulache în prefața cărții, Eliza Puşcoi introduce pagini de istorie văzută prin ochii unui copil (ultima parte a comunismului şi căderea regimului Ceauşescu), auzită în poveştile bunicului Ion (al doilea război mondial, momentul alierii cu Rusia). Jurnalistul şi scriitorul Alfredo Venturi vorbeşte în prefața cărții Elizei despre tonul pe care autoarea îl foloseşte în descrierea evenimentelor din '89: ,....sunt spuse cu o atingere delicată şi modestă, care le oferă ca o experiență prețioasă de viață”. (Puşcoi 2020, 12)

Maniera narativă a autoarei, în ciuda suferinței interioare, îmbină atitudinea serioasă cu elemente amuzante. Descrierile în detaliu ale fiecărui moment, loc, sunet, parcă invită cititorul la vizionarea unui film în care fiecare simț este stimulat - frigul, foamea, frica, căldura de la bunici, liniştea, singurătatea.

Aspettavo con lo sguardo abbassato e triste, perdendomi sugli stivali di tutti loro, ben lucidati, pregando di ricevere un secondo invito. Ora, però, ero davvero preoccupata perché la madre dei bambini poteva anche ignorarmi. C'era questo rischio, certamente, ma mia madre mi disse che era maleducazione accettare subito; e quasi quasi mi diedero le lacrime poiché l'avevo ascoltata proprio in quel momento, quando nemmeno c'era. (Puscoi 2020, 30)

(Aşteptam cu privirea coborâtă şi tristă, pierzându-mă în cizmele tuturor, bine şlefuite, rugându-mă să primesc o a doua invitație. Acum, însă, eram foarte îngrijorată pentru că mama copiilor mă putea ignora. Exista acest risc, desigur, dar mama mi-a spus că este nepoliticos să accept imediat; şi aproape că-mi dădeau lacrimile pentru că o ascultasem în acel moment, când nici măcar nu era acolo.)

Fiecare moment, acțiune sau obiect se transformă simbol. Paltonul roşu cumpărat de Gina, dar care i-a rămas mic, cuprinde aproape toată simbolistica romanului - roşul înseamnă sânge viață, viu, tinerețe; paltonul este scurt la mâneci, strâmt sugerează dorința de căldură, de comfort din partea mamei de altfel rece şi indiferentă, oferindu-i sentimentul de nesiguranță, de dezorientare, fapt ce reiese şi din pasajul în care este descris momentul în care, în drum spre bunici, realizează că de fapt se învârte în cerc, că a pierdut punctul de reper: 
La sera, su cui avevo tanto contato, lasciò definitivamente posto al buio e se prima la neve aveva brillato, ogni tanto, ora non la vedevo più. Mi era chiaro però, come la luna che avrei voluto vedere con disperazione nel cielo, che stavo attraversando il campo aperto. Là sentivo il rumore dell'inverno intensificarsi e che mi fischiava forte nelle orecchie, nonostante fossi ben coperta. La neve mi appesantiva le ciglia, ma continuavo lo stesso a tenere gli occhi aperti anche se non vedevo niente. Era terribile. Inoltre dovevo alzare la gamba prima una poi l'altra, mentre avanzavo faticosamente nel manto che si era alzato ormai più delle mie ginocchia. Sentivo anche il gufo, ma sempre più da lontano, oforse me lo immaginavo nel suo piccolo bosco, al sicuro. Per un po' di tempo camminai in cerchio, per ritrovare $i$ solchi, ma senza successo. (Puscoi 2020, 55)

(Seara, pe care mă bazam atât de mult, a lăsat definitiv loc întunericului si dacă înainte zăpada strălucea, din când în când,acum nu o mai vedeam. İmi era limpede, însă, ca luna pe care voiam cu disperare să o văd pe cer, că traversam câmpul deschis. Acolo auzeam zgomotul iernï care se intensifica şi îmi şuiera tare în urechi, în ciuda faptului că eram bine acoperită. Zăpada îmi făcea genele grele, dar continuam să țin ochii deschişi chiar dacă nu vedeam nimic. Era teribil. În plus, trebuia să ridic piciorul întâi unul apoi celălalt, în timp ce avansam din greu prin zăpada, care acum se ridicase mai sus de genunchii. Auzeam şi bufnița, dar din ce în ce mai departe, sau poate mi-am imaginat-o în păduricea ei, în siguranță. De ceva timp am umblat în cerc, să găsesc brazdele, dar fără succes.)

În capitolul „Ma perché le donne accettano di essere maltrattate?” („De ce femeile acceptă să fie maltratate?”), Eliza atinge o temă sensibilă încercând să ofere câteva explicații prin intermediul protagonistei - copil:

Non capivo perché una bella donna, intelligente e autonoma come mia madre, che lavorava sin dall'età di diciott'anni, non avesse già preso la decisione definitiva di lasciare colui che non la proteggeva affatto e che le rendeva la vita un incubo. (Puscoi 2020, 225)

(Nu înţelegeam de ce o femeie frumoasă, inteligentă şi autonomă ca mama mea, care lucra încă de la optsprezece ani, nu luase deja decizia finală de a-l părăsi pe cel care nu o proteja deloc şi care-i făcea viața un coşmar.)

Romanul se încheie concluziv a tot ceea ce a trăit protagonista acordându-i cititorului prilejul de a reflecta: „... nu trecutul îți spune cine fusesei, ci cine ai ales tu să fii...” (Puşcoi 2020, 258) şi nu înainte de a depune mărturie despre veridicitatea faptelor:

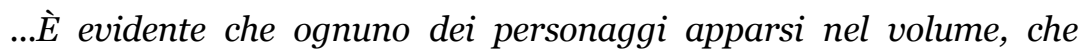
interagiscono con me o semplicemente si affacciano nei testi, hanno dato un contributo speciale, alcuni di loro accettando di apparire nel mio libro, prestando quindi la propria figura. Pertanto un grazie enorme e rispettoso va a ciascuno degli amici e alla gente di Sarbi e Bucarest. (Puscoi 2020, 273) 
(...Este evident că fiecare dintre personajele apărute în volum, care interacționează cu mine sau apar pur şi simplu în texte, au adus o contribuție specială, unii dintre ei acceptând să apară în cartea mea, împrumutând astfel propria lor figură.)

Capacitatea de a privi cu ochi limpezi propriul pământ îndepărtat (şi de a-l iubi, deşi anii copilăriei apar substanțial nefericiți) defineşte un portret de grup, în sensul că se prezintă ca un roman autobiografic al unei întregi generații, al acelora care au trăit în România lui Ceauşescu. Narațiunea păstrează, de asemenea, trăsături ale romanului de instruire, sub forma poveştii unui copil, al unei adolescente care vrea să îşi ia viața în mână, dar care, datorită faptului că este diferită, se regăseşte „străină” în propriul său pământ.

\section{Concluzii}

Ceea ce se evidențiază în producția actuală a literaturii migrației italiene este prezența vizibilă a scriitorilor români de sex feminin. Numărul mare de autori este doar una dintre particularitățile acestui corpus, dar este clar că, într-un anumit sens, comparația dintre două genuri de scriere, cel masculin şi cel feminin, reprezintă o trăsătură fundamentală a discursului literar orientat, în unele cazuri, pe o tematică specială. Urmărind studiile teoreticianului feminist italian Rosi Braidotti, se poate spune că femeile migrante, având puține drepturi politice sau aflate în afara căilor instituționale, se simt mai des fără patrie, pentru că, majoritatea dintre ele, şi în țara de origine nu au posibilitatea de a-şi face auzită vocea. Din acest motiv, Braidotti a inventat conceptul de „subiect nomad” (Braidotti 2005), o depăşire a termenului de „migrant”, întrucât nomadul face ca granițele să fie nedeterminate şi înlocuieşte ideea de limbă maternă cu cea a unui loc lingvistic, pierzând complet simțul exilului sau al diasporei şi păstrând trăsăturile identitare a culturilor prin care trece. În acest sens, scriitorii migranți de limbă italiană expun în operele lor nostalgia pentru o patrie pierdută, nevoia de a construi o realitate nouă sau o critică ironică a țării gazdă.

\section{Bibliografie}

Braidotti, R. (2005). Soggetto nomade, ediție A. M. Crispino. Roma: Donzelli.

Coman, Ingrid Beatrice. (2005). La città dei tulipani. Ferrara: Tufàni.

Coman, Ingrid Beatrice. (2008). Tè al samovar. Voci dal gulag sovietico, pref. di Monica Joita. Torino: L'Harmattan.

Coman Ingrid Beatrice. (2008). Non spegnete la luce. Racconti. Milano: La Memoria del Mondo Libreria Editrice.

Coman, Ingrid Beatrice. (2010). Per chi crescono le rose, postfazione di Luca Bistolfi. Milano: Edizioni Uroboros. 
Coman, Ingrid Beatrice. (2012). Villaggi Senza Madri. Casa Editrice Rediviva Edizioni. Puşcoi, Eliza. (2020). Eli Col Cappotto Rosso. Monte Compatri: Edizione Controluce.

\section{Sitografie:}

A.D.R.I., Associazione. "Badante Pentru Totdeauna (I) De Ingrid Beatrice Coman.” Associazione Donne Romene In Italia - A.D.R.I., 2020, https://dumitrachesilvia.wordpress.com/2015/04/24/badante-pentrutotdeauna-i-de-ingrid-beatrice-coman/. Accesat 19 iunie 2020.

"Books - Ingrid Beatrice Coman.” Ingrid Beatrice Coman, 2020, https://ingridbeatrice coman.com/books/. Accesat 19 iunie 2020.

"BIOGRAPHY - Ingrid Beatrice Coman." Ingrid Beatrice Coman, 2020, https://ingrid beatricecoman.com/biography/\#1482147212416-b3c99e7d-cbb3. Accesat 19 iunie 2020.

"Donne Migranti Che Scrivono In Italiano: Il Caso Della Romania - Concorso Letterario Nazionale Lingua Madre.” Concorsolinguamadre.It, 2020, https://concorso linguamadre.it/ donne-migranti-che-scrivono-in-italiano-il-caso-dellaromania/. Accesat 19 iunie 2020.

Melo, Roberto. Literatura Română A Migrației Româneşti - Repere Şi Analize. 2020, p. 496, http://www.diacronia.ro/ro/indexing/ details/V398/ pdf. Accesat 19 iunie 2020.

Pavel Cassese, Diana. "Recensione N. 33: "Il Villaggio Senza Madri” Di Ingrid Beatrice Coman.” Letterranza, 2020, http://www.letterranza.org/ recensione-n-33-ilvillaggio-senza-madri-di-ingrid-beatrice-coman/. Accesat 19 iunie 2020.

"Villaggi Senza Madri." D.It Repubblica, 2020, https://d.repubblica.it/ attualita/2013/o5/14/news/infanzia_romania_orfani_bianchi-1648586/. Accesat 19 iunie 2020. 